\title{
Good Country Index - V4 Countries Comparison
}

\begin{abstract}
Michaela Čiefová
Dr. Department of International Economic Relations and Economic Diplomacy, Faculty of International Relations, University of Economics in Bratislava
\end{abstract}

Natália Goda

$\mathrm{PhD}$ Candidate, Department of International Economic Relations and Economic Diplomacy, Faculty of International Relations ,University of Economics in Bratislava

\begin{abstract}
There are currently many indices ranking countries based on their national competitiveness, happiness, human development and other criteria. A couple of years ago, the Good Country Index was introduced, whose purpose is to measure how a country contributes to the wellbeing of not only its own citizens, but the whole humanity and the planet. The fundamental idea behind the Index is the significant influence of globalisation on spreading both positive and negative trends in the world. Hence it is vital for countries to cooperate in order to handle the negative effects of globalisation. The Index consists of seven dimensions, namely Science \& Technology, Culture, International Peace \& Security, World Order, Planet \& Climate, Prosperity \& Equality, and Health \& Wellbeing. In the present paper we compare the Index calculations of the Visegrad Group countries and analyse the reasons behind their respective overall positions, as well as ranking within individual sub-indices. Our special attention is dedicated to culture-related phenomena. Based on the analysis, we offer suggestions to improve the current state in the areas where the countries are less successful. The dominant research method utilised is comparative analysis.
\end{abstract}

Keywords: Good Country Index, comparison, Czech Republic, Hungary, Poland, Slovakia

\section{Introduction}

Countries can be ranked via numerous indices, such as Global Competitiveness Index (WEF, 2018), Human Development Index (UNDP, 2019), Index of Economic Freedom (Heritage Foundation, 2019), Environmental Performance Index (Yale University, 2018) and many more. Each index has its unique structure and a specific purpose. Besides, there are (sometimes considerable) differences in numbers of countries involved in them. A relatively new way of countries ranking is the Good Country Index (hereinafter referred to as "the Index") measuring how a country contributes to well-being of the humanity, or, on the contrary, how it is a burden for the world. The Index shall contribute to the ongoing debate on whether countries follow only their own interest, or whether they take also interests of the others into account (Good Country, 2019a).

The Index is based on a large scale of data acquired from international organisations, such as the United Nations (Good Country, 2019c), and includes seven dimensions, namely Science \& Technology, Culture, International Peace \& Security, World Order, Planet \& Climate, Prosperity \& Equality, and Health \& Wellbeing. Each dimension is further divided into five categories. Hence the overall Index represents a complex tool incorporating 35 indicators for measurement (Good Country, 2019b). As Becker et al. (2017) point out, the Index is comprised of "direct measurements of world-friendly or worldunfriendly behaviour" and several indirect indicators.

Unlike other indices, such as the Human Development Index, the Good Country Index does not consider the existing infrastructure creating countries' development. On the contrary, the Index rather looks at external outputs. Therefore, the countries included in the Index may provide less for their own citizens (Tan and Dramowicz, 2016). Krylová and Barder (2014) see the purpose of the Index in the emphasis it puts on the impacts that policies of a country have on other countries.

Applying the Index, we compare the countries belonging to the Visegrad Group, i.e. the Czech Republic, Hungary, Poland and Slovakia (hereinafter referred to as "V4"). Firstly, we provide an outline of the development of their "goodness" since 
2014 until the last edition of the Index in 2018. Secondly, we focus on the 2018 edition and discuss individual components of the Index in detail. Throughout the paper, we pay special attention to culture-related issues. The research is concluded by a summary of strengths and weaknesses of the analysed countries, and by recommendations for the improvement of the current state.

We believe that debate on this topic is relevant also in the context of nation branding, cultural and public diplomacy, as these are currently very dynamic areas of research, and subject to contemporary economic, social and political developments (Čiefová, 2018). Moreover, nation branding has also importance in foreign political relations (Čiefová and Goda, 2019).

\section{Literature Review}

As already emphasised, the Good Country Index is a rather new tool; it was developed only in 2014. Hence, the literature on it and directly related phenomena is rather scarce. In spite of that, there are several relevant works to be mentioned here.

Becker et al. (2017) provide tools designated for users and developers of composite indicators helping them assess the impacts of the weights of individual components incorporated within the overall indicator. The authors emphasise the significance of weights ascription to the overall scores of indices. Among others, they discuss this in conjunction with the Good Country Index and conclude that adjusting the Index weights would visibly amend the country rankings.

Tan and Dramowicz (2016) conducted several analyses using the Index, such as spatial analysis including autocorrelation to identify similarities in countries and their neighbours, or non-spatial analysis to measure relationships between the Index and other relevant indices. The authors subsequently grouped the countries into clusters. They also investigated whether the substitution of the individual components of the Index by corresponding global indices may enable using "the global indices as proxy indicators to evaluate a country's 'goodness' ".

Krylová and Barder's work (2014) can be viewed as constructive criticism of the Index, as they analyse its components and offer suggestions and recommendations for the Index to be more adequate. They are aware of the challenge of index creation, as well as the importance of proper data source selection. Referring to their own experience with the Commitment to Development Index, they underline the issues with data availability or source credibility. In this context they express their not being completely convinced by the selection of indicators and point out the fact that needed data are not always available. Regarding culture they state this dimension is based on the assumption that exporting a culture contributes to wellbeing of the others. In the authors' opinion, some might disagree with this premise. They see the component World Order as "perhaps the most contentious", arguing that it penalises countries that generate refugees, which is unrightful in case of their suffering from conflicts or natural disasters. As example they use Vietnam that does not score very well in this dimension due to many Vietnamese people living abroad. On the other hand, Iceland or Norway are successful in the ranking, despite the inflow of economic migrants in the past. Their advice is therefore to measure the contemporary flow of refugees.

An in-depth analysis shows certain similarities between the Good Country Index and the Commitment to Development Index (CDI). They both are composed of seven categories, which, however, differ (Krylová and Barder, 2014). Besides, the $\mathrm{CDI}$ ranks 27 countries - the richest ones in the world - based on their being dedicated "to policies that benefit people living in poorer nations," (CGDEV, 2019).

\section{Methodology}

In the present contribution, mainly methods of qualitative research are applied, with comparative analysis being the dominant one. We compare the results for all editions of the Index for the V4 countries, i.e. for the years 2014, 2016, 2017, and 2018. Our special attention is dedicated to the most recent edition or the Index - Version 1.3, which reflects the situation for the year 2018. We conduct comparative analysis of the data for the four countries, analyse potential reasons for the given state, and accentuate their strengths and weaknesses. We specifically look at the category of Culture. In the paper, we also utilise descriptions and graphical demonstrations to better illustrate the findings. One of the methods is bibliographic recherche, although literature scarcity is a challenge to be faced. At the end of our research, we provide policy recommendations for improvements of the current state. 


\section{Analysis and Discussion}

As already stated above, the Index consists of seven categories, with each of them further incorporating five indicators (Table 1). Taking into consideration the complexity of the Index, due to the limited space of the contribution we disregard detailed analysis of all 35 indicators, and rather focus on the categories as a whole.

\begin{tabular}{|c|c|}
\hline Category & Indicator \\
\hline $\begin{array}{l}\text { 1. Contributions to Science \& } \\
\text { Technology }\end{array}$ & $\begin{array}{l}\text { 1. International students } \\
\text { 2. Journal exports } \\
\text { 3. International publications } \\
\text { 4. Nobel prizes } \\
\text { 5. Patents }\end{array}$ \\
\hline 2. Contributions to Culture & $\begin{array}{l}\text { 6. Creative goods exports } \\
\text { 7. Creative services exports } \\
\text { 8. UNESCO dues in arrears as \% of contribution } \\
\text { 9. Freedom of movement, i.e. visa restrictions } \\
\text { 10. Press freedom }\end{array}$ \\
\hline $\begin{array}{l}\text { 3. Contributions to International } \\
\text { Peace and Security }\end{array}$ & $\begin{array}{l}\text { 11. Peacekeeping troops } \\
\text { 12. Dues in arrears to UN peace keeping budgets as } \% \text { of contribution } \\
\text { 13. International violent conflict (negative indicator) } \\
\text { 14. Arms exports (negative indicator) } \\
\text { 15. Internet security }\end{array}$ \\
\hline 4. Contributions to World Order & $\begin{array}{l}\text { 16. Charity giving } \\
\text { 17. Refugees hosted } \\
\text { 18. Refugees generated (negative indicator) } \\
\text { 19. Birth rate (World Bank as negative indicator). } \\
\text { 20. UN Treaties signed }\end{array}$ \\
\hline $\begin{array}{l}\text { 5. Contributions to Planet and } \\
\text { Climate }\end{array}$ & $\begin{array}{l}\text { 21. Ecological footprint (negative indicator). } \\
\text { 22. Reforestation since } 1992 \\
\text { 23. Hazardous pesticides exports (negative indicator). } \\
\text { 24. CO2 emissions (negative indicator). } \\
\text { 25. Ozone (negative indicator). }\end{array}$ \\
\hline $\begin{array}{l}\text { 6. Contributions to Prosperity and } \\
\text { Equality }\end{array}$ & $\begin{array}{l}\text { 26. Open trading } \\
\text { 27. UN volunteers abroad } \\
\text { 28. Fairtrade market size } \\
\text { 29. FDI outflows } \\
\text { 30. Development assistance }\end{array}$ \\
\hline $\begin{array}{l}\text { 7. Contributions to Health and } \\
\text { Wellbeing }\end{array}$ & $\begin{array}{l}\text { 31. Food aid } \\
\text { 32. Pharmaceutical exports } \\
\text { 33. Voluntary excess donations to the WHO } \\
\text { 34. Humanitarian aid donations } \\
\text { 35. International Health Regulations Compliance }\end{array}$ \\
\hline
\end{tabular}

\section{Table 1: Composition of the Good Country Index}

Source: Authors' own elaboration based on https://www.goodcountry.org/index/source-data.

The Index was introduced in 2014 and four versions of it have been published so far. The V4 countries have developed over the years in the overall ranking of the Index. Anholt and his team have created a total of four global measurements over five years. We can see the Index is not released regularly every year, as the edition 2015 is missing. In every measurement, the countries have a distinct position in the worldwide order. It is important to notice that in each survey a different number of countries is compared and therefore the overall positioning may change slightly. Version 1.0 was created in 2014 and the overall ranking compared 125 countries. Version 1.1 was created 2 years later and, same as in Version 1.2 from 2017, 163 countries were compared. The latest Version 1.3 was created in 2018 and the number of 
compared countries decreased by 10 in relation to the previous year. Hence, 153 were contrasted in 2018 ranking (Good Country, 2019b).

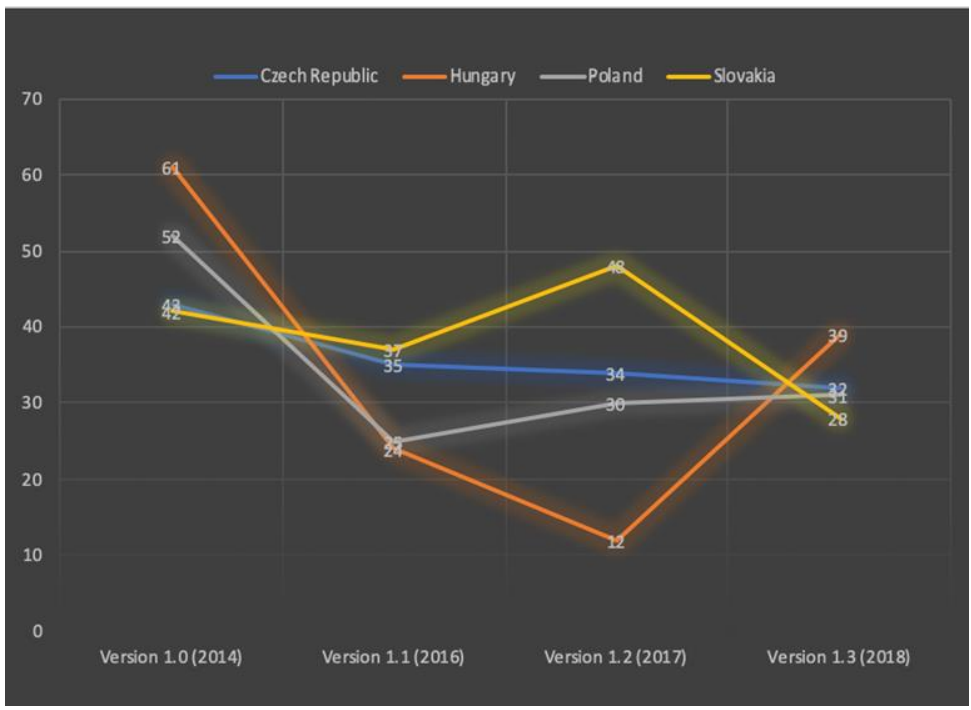

Graph 1: Development of the Overall Rank of the V4 Countries

Source: Authors' own elaboration based on https://www.goodcountry.org/index/results.

In the Graph 1 we can see the development of the V4 countries within the whole period of the Index existence. Each of the V4 countries demonstrates an improvement in the overall assessment in 2016 compared to 2014. In this period (20142016), Hungary improved its position the most among the V4 countries. It scored $61^{\text {st }}$ in the first year of evaluation compared to $24^{\text {th }}$ in 2016. The Czech Republic, as the only V4 country, improved annually in the overall ranking, despite the fact that it never ranked best among them. The best rated country among the V4 countries was Hungary in 2017 when it ranked $12^{\text {th }}$ worldwide. According to the Graph 1, we can see that after 2017 there was a rapid deterioration of the situation within a year and Hungary occupied $39^{\text {th }}$ place worldwide, which is the biggest difference from year to year compared to the V4 countries. According to the results, this quick change in the ranking can be attributed to radical change in arms export and FDI outflows, whose number also significantly changed. Poland as well as Slovakia improved from year to year in the overall ranking, except for 2017, when we see a deterioration in the overall ranking in both cases. In case of Slovakia, we see changes particularly in the category of culture, where numbers in export of creative goods significantly decreased. Likewise, the change between the years can be attributed to decrease in the number of the FDI outflows. In case of Poland, the change in overall ranking happened due to decreased food and pharmaceutical aid. In 2014, Slovakia was the best rated country worldwide among the V4 countries, followed closely by the Czech Republic. This year, Hungary had the worst ranking of the V4 countries, which it managed to change immediately in the next 2016 rating of Version 1.1. In the latest ranking (Version 1.3), Slovakia ranked $28^{\text {th }}$, the best among the V4 countries (Good Country, 2019b). 


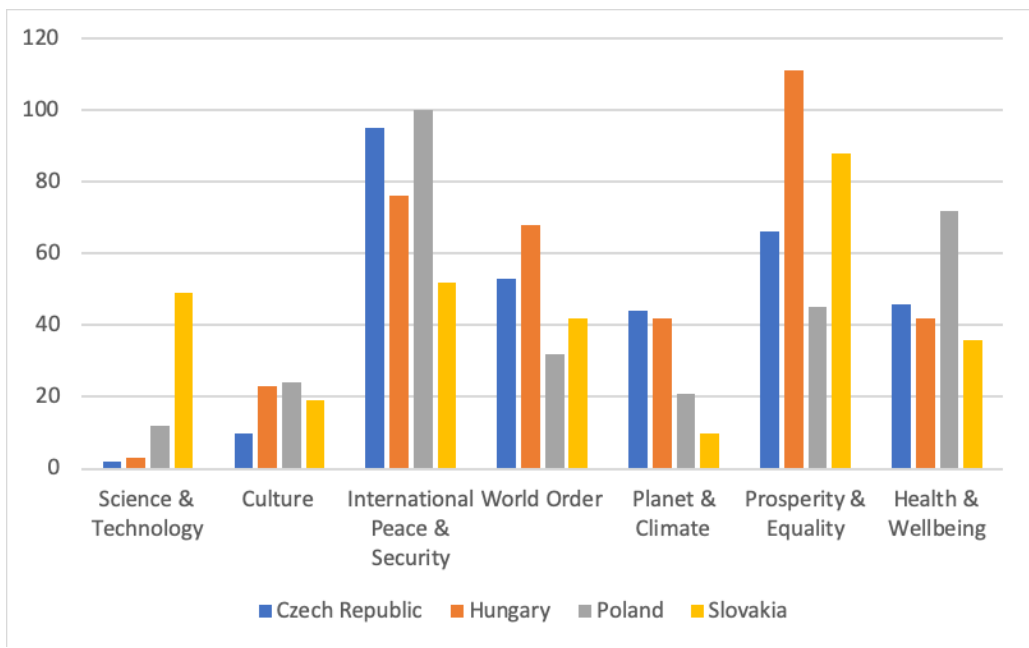

Graph 2: V4 Countries Rankings in the Version 1.3

Source: Authors' own elaboration based on https://www.goodcountry.org/index/results.

So far, the latest version of the Index was released in 2018, comparing 153 countries. That year, all V4 countries were ranked in $1 / 3$ of the top-rated countries. The best ranked country was Slovakia as $28^{\text {th }}$, followed by Poland on the $31^{\text {th }}$ place. The Czech Republic was placed just behind Poland on the $32^{\text {th }}$ place and the worst rated V4 country was Hungary on the position 39 (Graph 2).

From the seven evaluated categories, the Czech Republic was the best in the Science \& Technology and Culture compared to the V4 countries, from which it was ranked $2^{\text {nd }}$ in the category Science \& Technology worldwide. Among the V4 countries, Poland was best placed in the categories World Order and Prosperity \& Equality. Slovakia received the highest number of the best rated categories. It was best placed in three categories, namely International Peace \& Security, Planet \& Climate, and Health \& Wellbeing. Although Hungary did not rank among the V4 countries in the best position in any of the above categories, it occupied the $3^{\text {rd }}$ place worldwide after the Czech Republic in the category Science \& Technology.

In a more detailed comparison, we observe the main differences between Slovakia (49th place) and the Czech Republic ( $2^{\text {nd }}$ place) in the Science \& Technology category, where Slovakia lags behind in the number of foreign students and in the number of scientists who were awarded the Nobel Prize. The number of publications in international journals also ensures that the Czech Republic was ranked on the $2^{\text {nd }}$ place worldwide.

As mentioned above, Slovakia has the best results among the V4 countries in the International Peace \& Security category. In comparison with Poland $\left(100^{\text {th }}\right)$, which received the worst ranking from the V4 countries, Slovakia ranked $52^{\text {th }}$ due to low arms exports and higher numbers of peacekeeping troops sent overseas for the UN missions.

As a strong Christian country, Poland was ranked $32^{\text {nd }}$ in the World Order category. It was ranked higher than the V4 countries by birth rate and high number of UN treaties signed as proxy for diplomatic action and peaceful conflict resolution.

Another category in which Slovakia was the most successful among the V4 countries (10) was Planet \& Climate category. Slovakia leaves the lowest ecological footprint of the V4 countries and dominates compliance with signed multilateral environmental agreements.

Despite the low development aid, Poland ranked $45^{\text {th }}$ in the Prosperity \& Equality category worldwide and 1 st in the V4 countries thanks to open trading and FDI outflows. Slovakia ranked best in the last category of Health \& Wellbeing and achieved the highest position in comparison with the V4 countries thanks to the Pharmaceutical export and food aid.

For the purpose of this paper, we elaborate a little more on the component of culture. The largest differences in the Culture category are seen in the V4 countries between the Czech Republic $\left(10^{\text {th }}\right)$ and Poland $\left(24^{\text {th }}\right)$. Both countries are part of the 
European Union, thanks to which we see only small differences in the number of countries that do not need visa to enter the Czech Republic and Poland, because they adhere to the principles of the freedom of movement. The reason of the difference between these countries in the Culture category is mainly press freedom, in which the Czech Republic is ahead, and also Export of creative goods. In all four rankings, the Czech Republic received the best evaluation from the V4 countries in the Culture category. Interesting is the fact that despite the overall improvement of the V4 countries between the years 2014-2018, in case of culture we see deterioration in Poland, Hungary and the Czech Republic as well. The Czech Republic had the slowest decrease which means only minus one place per year. According to the results, this is due to decreased export of creative services. In case of Poland and Hungary, deterioration is more significant. Compared to 2014 when Poland occupied $16^{\text {th }}$ place, in 2018 it occupied $24^{\text {th }}$ place worldwide. In 2014, Hungary was on position 13 worldwide, compared to 2018 and position 23. In both cases, this development was due to deterioration of the freedom of media and press as well as due to decrease in export of creative services (Good Country, 2019b).

Although the differences in placement of the countries between the individual Versions of the Index and the components might sometimes seem massive, one again needs to keep in mind the diversity of numbers of countries compared within the four Index editions.

\section{Conclusion}

The objective of this paper was to conduct a comparative analysis of the V4 countries according to the Good Country Index. The Index was first introduced in 2014, and there have been four editions of it so far. When comparing the countries results, it needs to be taken into consideration that the number of countries included in the comparison is not constant in each Index edition. A country's position should therefore be viewed as relative. Another issue is the data availability, what is also highlighted by Krylová and Barder (2014).

The aim of this contribution was to analyse the general development of the V4 countries within the framework if the Index existence. Next, we analysed the latest version of the Index, i.e. the year 2018, in more detail. We compared the countries within all seven components of the Index. Our analysis has illuminated the strengths and weaknesses of the V4 countries in the Index components.

Based on the analysis of the 2018 edition, the countries achieve the best and the worst results in the following categories. The Czech Republic is successful predominantly in the Science \& Technology category, which can be attributed for instance to publications in international journals. On the contrary, the worst score of the Czech Republic is in the category International Peace \& Security, influenced also by a negative indicator - arms exports. Since the score of the Czech Republic in this category is $95^{\text {th }}$ position out of 153 , it is the area the policy makers should pay attention to and look for proper improvement measures. Same as in case of the Czech Republic, also Hungary demonstrates success in the sphere of science, research, and technology, and thus thanks to publications or Nobel prizes. On the other hand, the category Prosperity \& Equality is much less favourable in Hungary. There is a room to increase FDI outflows or development assistance, which represent negative indicators. Besides, Hungary can still motivate people to act as UN volunteers abroad. Poland also scores well in the category Science \& Technology, particularly thanks to awarded Nobel prizes and publications. Even though, we would recommend taking measures to attract more international students, for example by means of cultural diplomacy, and to increase the number of patent holders. The least successful dimension of the Index of Poland is International Peace \& Security, with exporting arms being a negative indicator. As the single one out of the V4 countries, Slovakia ranks the best in the Planet \& Climate category, mainly because of environmental agreements compliance and consumption of substances negatively impacting the ozone layer. In this category, Slovakia can still improve its use of renewable energy, as it represents a relatively low percentage of the overall energy mix. We believe, solar and wind energy could be a solution in certain areas of the country, although such step would surely require considerable financial input. In contrast to that, the worst position of Slovakia is in the category Prosperity \& Equality, with a negative indicator concerning contributions to development assistance, or FDI outflows. We especially consider the area of development assistance to be a crucial element of countries' "goodness". Being a direct way of contribution to the wellbeing of less developed countries, Slovakia still has potential to improve in this sphere. In our opinion, one of the ways to do so is to become more involved in international cooperation concerning projects aimed at development aid. Moreover, a country can take initiative and be more actively implementing development projects even by its own.

Regarding the cultural factor we can conclude, all four countries are relatively successful in their contribution to the outside world. In the latest Index edition, all of them scored in top 24 countries (out of 153). In Poland, exports of creative goods 
are on a very good level. On the other hand, the country's disadvantage can be seen in press freedom. Both Slovakia and the Czech Republic achieved favourable results in exports of creative goods, press freedom, or freedom of movement. Some improvement can be made in the area of exports of creative services. The freedom of press seems to be the most serious problem in Hungary. Hindering press and the media from covering a broad spectrum of topics and controlling the content is in contradiction with the principles of democracy. It is an interesting finding that both Poland and Hungary demonstrate a certain lack of press freedom, as guaranteeing freedom of expression is also one of the conditions to be fulfilled when applying for the EU membership according to the Lisbon Treaty (EC, 2019); yet both countries are already EU Member States. Should it be too difficult for the countries to improve in this matter, we would at least recommend preventing the current situation from worsening. On the other hand, Hungary's results regarding exports of creative goods and creative services, and freedom of movement can be evaluated as positive.

We have already emphasised the complexity of the Index. Due to limited space, it is not possible to thoroughly discuss all 35 indicators in relation to all four countries. However, we are convinced the Index can provide policy makers, organisations as well as individuals with incentives to consider the areas where a country can improve. We believe, in some cases it would be feasible to take improvement measures and thus to provide more for the others.

\section{References}

[1] BECKER, W., SAISANA, M., PARUOLO, P., VANDECASTEELE, I. (2017). Weights and importance in composite indicators: Closing the gap. Ecological Indicators. 80, 12-22. https://doi.org/10.1016/j.ecolind.2017.03.056.

[2] CENTER FOR GLOBAL DEVELOPMENT (CGDEV) (2019). The Commitment to Development Index 2018. Retrieved from: https://www.cgdev.org/commitment-development-index-2018. Accessed on 16 August 2019.

[3] ČIEFOVÁ, M. (2018). Selected issues of cultural diplomacy. Almanach. 13, 2, 4-13.

[4] ČIEFOVÁ, M., GODA, N. (2019). Význam nation brandingu pre Slovensko: súčasné trendy a výzvy. Economic, Political and Legal Issues of International Relations 2019. Volume of Scientific Papers. 91-98.

[5] EUROPEAN COMMISSION (EC) (2019). Freedom of expression and media. Retrieved from: https://ec.europa.eu/neighbourhood-enlargement/policy/policy-highlights/freedom-of-expression-andmedia_en. Accessed on 27 August 2019.

[6] GOOD COUNTRY (2019a). About the Good Country Index. Retrieved from: https://www.goodcountry.org/index/about-the-index. Accessed on 26 July 2019.

[7] GOOD COUNTRY (2019b). Results. Retrieved from: https://www.goodcountry.org/index/results. Accessed on 2 August 2019.

[8] GOOD COUNTRY (2019c). Source Data. Retrieved from: https://www.goodcountry.org/index/source-data. Accessed on 2 August 2019.

[9] HERITAGE FOUNDATION (2019). 2019 Index of Economic Freedom. Retrieved from: https://www.heritage.org/index/. Accessed on 31 July 2019.

[10] KRYLOVÁ, P., BARDER, O. (2014). What Is Good about the Good Country Index? Center for Global Development. Retrieved from: https://www.cgdev.org/blog/what-good-about-good-countryindex?fbclid=IwAR3cyOJC4yP-uZb1bOWxbJUq8QYugjWXGIpzcV0j2pR2jC57xYLRccSGcZO. Accessed on 16 August 2019.

[11] TAN, C., DRAMOWICZ, K. (2016). Geovisualization and analysis of the Good Country Index. IOP Conference Series: Earth and Environmental Science. doi:10.1088/1755-1315/34/1/012037.

[12] UNITED NATIONS DEVELOPMENT PROGRAMME (UNDP) (2019). Human Development Index (HDI). Retrieved from: http://hdr.undp.org/en/content/human-development-index-hdi. Accessed on 31 July 2019.

[13] WORLD ECONOMIC FORUM (WEF) (2018). The Global Competitiveness Report 2018. Retrieved from: http://reports.weforum.org/global-competitiveness-report-2018/. Accessed on 31 July 2019.

[14] YALE UNIVERSITY (2018). Environmental Performance Index (EPI). Retrieved from: https://epi.envirocenter.yale.edul. Accessed on 31 July 2019.

\section{Acknowledgements}

This article is part of the project of young teachers, researchers and PhD students named "Cultural Diplomacy and Soft Power in the Context of Countries' Economic Interests" (Kultúrna diplomacia a mäkká moc v kontexte ekonomických záujmov štátu) no. I-19-101-00. 